\title{
Synthesis
}

\section{Bioenergy, Sustainability and Trade-offs: Can we Avoid Deforestation while Promoting Biofuels?}

\author{
Pablo Pacheco', D. Andrew Wardell', Laura German², Francis X. Johnson³, Neil Bird', Jan Willem van Gelder5, \\ Hannes Schwaiger ${ }^{4}$, George Schoneveld ${ }^{5}$, Krystof Obidzinski', Manuel Guariguata', Margaret Skutsch ${ }^{6}$, Omar Masera ${ }^{6}$, \\ Yan Gao ${ }^{6}$, Graham von Maltitz, Wouter M.J. Achten", Louis V. Verchot', Heru Komarudin' and Rubeta Andriani'
}

\section{Key findings}

- The World Exhibition held in Paris in 1900 demonstrated Rudolph Diesel's eponymous engine running on groundnut oil. Vegetable oils were used in diesel engines for the next 20 years before being replaced by cheaper fossil-fuel-derived alternatives (Smith and Searchinger 2012).

- Fluctuating oil prices, growing concerns about climate change and potential contributions to rural development have resulted in a more recent and growing interest in expanding the production and use of first-generation (1G) liquid biofuels from crops such as oil palm, sugar cane, soy and jatropha. Several countries have now established targets for biofuels as part of broader efforts to promote the production and use of renewable energy sources. The European Union's Renewable Energy Directive (EU RED), adopted in 2009, mandates each member state to ensure that at least 10\% of fuel consumed in the transport sector is derived from renewable sourcesincluding biofuels_-by 2020 (see http://ec.europa.eu/energy/ renewables/index_en.htm).

- The demand for land to expand the production of biofuel feedstocks grew throughout the period 2000-2010. However, there were large variations by region and type of feedstock. Global production and trade in biofuels is currently dominated by Brazil, Argentina, USA and the European Union (Figure 1). Only $9 \%$ of vegetable oils produced globally are used to make biofuels (May-Tobin et al. 2012). An estimated 16\% of biofuels produced in tropical regions were exported in 2009. However, in the same year, only $5 \%$ of oil palm production was used as feedstock for biofuels. Similarly, soy is grown predominantly for animal feed, with less than $15 \%$ by weight used in biofuel

\footnotetext{
Center for International Forestry Research, Indonesia

University of Georgia, USA

Stockholm Environment Institute, Sweden

Joanneum Research, Austria

Profundo, the Netherlands

National Autonomous University of Mexico, Mexico

Council for Scientific and Industrial Research, South Africa

University of Leuven, Belgium
}

production. The volume of biofuels derived from nonconventional feedstocks including jatropha remains negligible.

- Growing demand for biofuel feedstocks tends to add to existing pressures on forests in tropical regions, but these vary across regions. As $1 \mathrm{G}$ biofuels are derived from the sugars and vegetable oils in arable crops, expansion of these feedstock crops can have negative impacts on forests and food security due to direct and indirect land use changes (iLUC) (Fisher et al. 2009, Havlik et al. 2010). Direct land use changes are relatively easier to estimate for feedstocks such as sugar cane in Brazil, soy in Argentina and oil palm in Indonesia and Malaysia. In contrast, estimating the indirect land use changes and effects on forest conversion associated with the expansion of biofuel feedstocks is difficult. Further research is needed to address methodological challenges and help avoid premature conclusions.

- The local socio-economic impacts of biofuel feedstocks development are extremely variable. In some cases, feedstock plantations accrue benefits for job and income generation, and for boosting incomes of small-scale farmers engaged in production. In others, plantation development leads to a combined effect of livelihood displacement and limited opportunities for livelihood reconstruction following land and forest loss in cases where insecure tenure rights tend to prevail. To mitigate the risks of such negative impacts, some markets such as the European Commission (EC) have established a set of sustainability criteria to assist biofuel feedstock producers to certify that their operations are compliant. Additional research is needed to develop social sustainability components of these voluntary schemes.

- Different pathways can be adopted for biofuel development. Differences in the crops, in conversion technologies and in the inputs used to grow the crops tend to result in different global greenhouse gas (GHG) emissions per unit of energy for each type of fuel. Under $1 G$ technologies, emissions from land use change (LUC) dominate pathway emissions, if such emissions take place, while the lowest emission pathways use wood and agricultural residues as feedstock; however, they require 


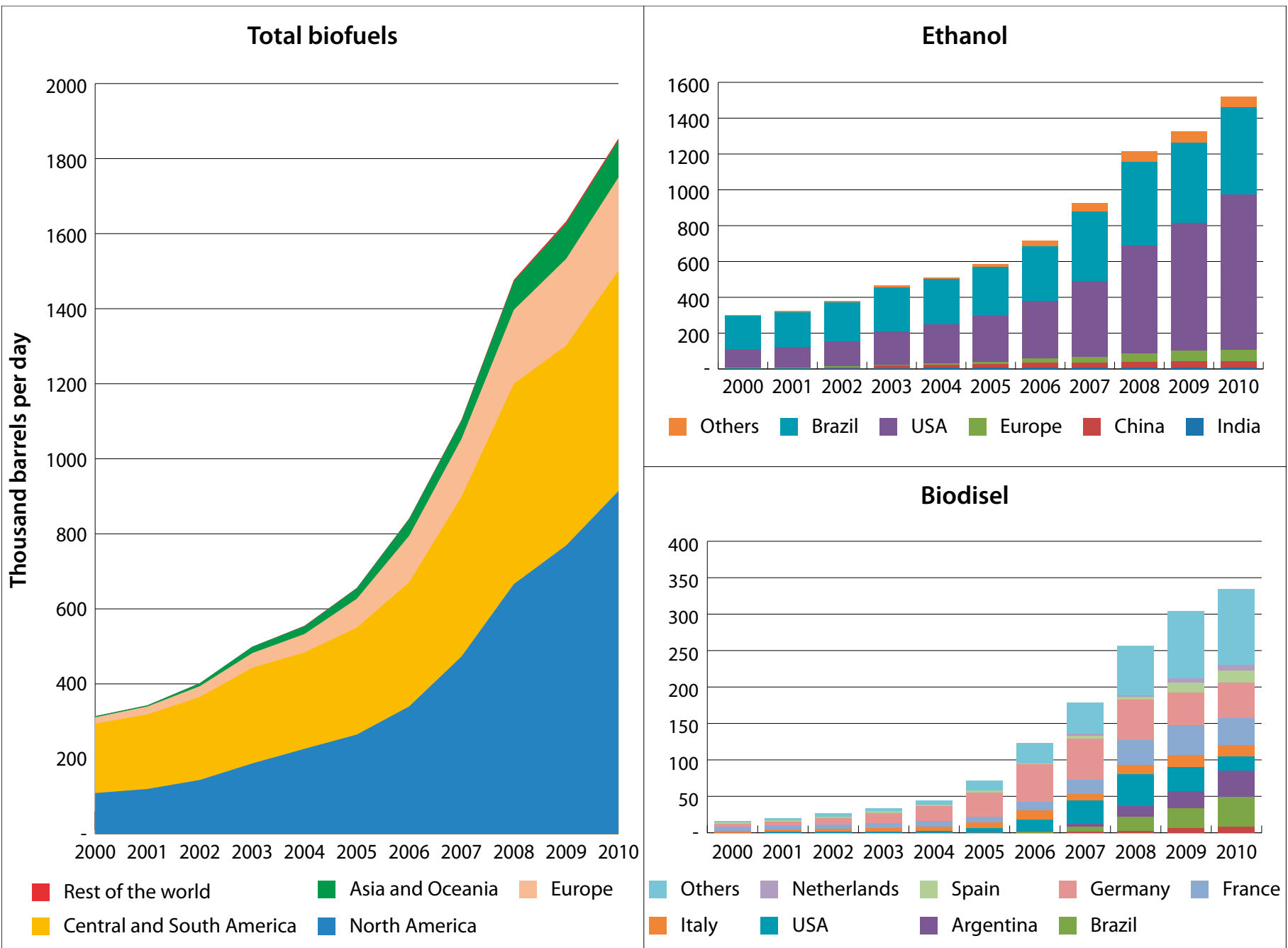

Figure 1. Total biofuels (ethanol and biodiesel) production by region and country, 2000-2010

Source: Energy Information Administration (EIA). 2012. Statistical database. http://www.eia.gov/countries/data.cfm (Accessed 2 July 2012)

second-generation (2G) conversion technologies. 2G biofuels are derived from woody crops, agricultural residues, waste and crops such as switch grass. While $2 \mathrm{G}$ biofuels may contribute to reducing GHG emissions, they may also place some pressures on forests (Popp et al. 2012). No product is yet on the market and $2 \mathrm{G}$ biofuels are currently not cost-competitive due to the high costs of converting woody, non-edible products into fuel (Eisentraut 2010).

- Biofuels constitute a contested approach to achieving reductions in global greenhouse gas (GHG) emissions. Current Life Cycle Analysis models indicate that some crop-based biofuels generate GHG savings compared with fossil fuels (for example, sugar cane). In other studies, carbon emissions generated from land conversion for biofuel feedstocks may take decades or even centuries to reverse (Achten and Verchot 2011). Full carbon accounting of biofuels is probably needed given the anticipated future growth in international trade in biofuels. Additional research is needed to account for emissions of $\mathrm{CO}_{2}$ emissions from vehicles using biofuels and $\mathrm{N}_{2} \mathrm{O}$ emissions associated with nitrogen fertiliser use (Smith and Searchinger 2011). The inclusion of responsibility for
GHG emissions from land use change in biofuel-producing countries in the EU RED for imported biofuels effectively extends responsibility beyond the United Nations Framework Convention on Climate Change (UNFCCC)/Kyoto requirements under which energy emissions are counted at the point of use.

\section{Key recommendations}

- Some of the costs of proving sustainability compliance will fall on developing countries and/or small farmers, which can be difficult for them to absorb in financial, technical or administrative terms. Technical and institutional capacitybuilding programmes, possibly through bilateral or multilateral agreements could offer a way to address these shortcomings.

- A combination of stronger regulations at different scales, along with market-based instruments is needed, through more 'hybrid' approaches, to influence the behaviour of large-scale investors in biofuel development.

- There is still important scope to reduce the environmental impacts of biofuel feedstock investments, while also promoting more inclusive business models and protecting the rights and livelihood options of customary land owners. 
- Financial institutions need to play a more significant role in shaping responsible investments in biofuels. Sustainability criteria need to be adopted in bank risk management, and applied to all forms of foreign public finance, including investments by state-owned companies.

- Additional research is needed to more accurately estimate indirect land use changes associated with the continued expansion of $1 \mathrm{G}$ and $2 \mathrm{G}$ biofuel feedstocks, develop valuechain accounting methods, develop and apply responsible financing policies, design more effective and integrated governance systems to reduce social and environmental costs and to assess the opportunities and constraints associated with a shift to $2 \mathrm{G}$ biofuels.

\section{Context}

Motivations to produce biofuels, included interests in mitigating GHG and controlling pollution, reducing national exposure to price volatility in oil and gas markets, addressing energy security, safeguarding foreign currency reserves and promoting the development of the agricultural sector, particularly in developing countries. The need to produce and provide energy to isolated areas is also a driver of biofuels development and has led to increased global demand for biofuels. Climate change mitigation policies have become an additional driver of increased demand for renewable energy sources and particularly for bioenergy. During the production, distribution and consumption of bioenergy, different types of greenhouse gas (GHG) emissions are released in the atmosphere. This is particularly important in the area of transport, the third largest GHG source after the energy sector, and deforestation. In the European Union (EU), GHG emissions in other sectors decreased 15\% between 1990 and 2007, while emissions from transport increased 36\% during the same period. Some of the sources of GHG emissions from bioenergy that are most difficult to capture are associated with direct and indirect emissions and removals associated with land use changes. The policy and investment frameworks developed to promote biofuel feedstocks in developing countries are not usually limited, however, to simply achieving reductions in GHG emissions. Other policy objectives include the stimulation of rural economies and smallholder production systems, food and energy security and the preservation of forests in what has often become a highly contested policy arena.

\section{European Union initiatives}

The Biomass Action Plan of the European Union (COM 2005/628, adopted on 7 December 2005) identifies various actions that will be taken to encourage the use of all kinds of biomass for renewable energy production. It sets out the EU Strategy for Biofuels with three aims:

- to promote biofuels in the EU and developing countries, ensuring that their production and use is globally positive for the environment and that they contribute to the objectives of the Lisbon Strategy taking into account competitiveness considerations:

- to prepare for the large-scale use of biofuels by improving their cost-competitiveness through the optimised cultivation of dedicated feedstocks, research into 'second generation' biofuels, and support for market penetration by scaling up demonstration projects and removing non-technical barriers;
- to explore opportunities for developing countries -including those affected by the reform of the EU sugar regime-for the production of biofuel feedstocks and biofuels, and to define the role of the EU in supporting the development of sustainable biofuel production.

The European Union (EU) has since been active in defining goals for renewable energy production. The Renewable Energy Directive (RED, adopted on 23 April 2009, 2009/28/EC), sets mandatory renewable energy targets for all Member States, including a target of a $10 \%$ share of renewable energy specifically in the transport sector, such that the EU will reach a $20 \%$ share of energy from renewable sources by 2020. The EU Member States were obliged to transpose RED into their national legislations by 5 December 2010. RED establishes sustainability criteria for biofuels in transport and bioliquids used for energy purposes other than transport, including electricity, heating and cooling. To receive national government support or count towards the mandatory national renewable energy targets of Member States, biofuels used in the EU, whether locally produced or imported, have to comply with sustainability criteria. The sustainability criteria require a minimum level of GHG savings compared with their fossil fuel comparators (as defined in RED), and ban the use of biofuels produced by clearing natural forests, on land with high biodiversity value or land with high carbon stocks.

Twelve voluntary schemes were approved by the EC up to August 2012. Operational criteria for proving compliance with the sustainability criteria were established in 2011. In December 2010, the EC published a report on indirect land use change (iLUC) (22 December 2010, COM/2010/0811). More recently, the EC presented its Communication 'Renewable Energy: Progressing towards the 2020 target' (31 January 2011, COM/2011/0031). The EC announced its preliminary proposals on how to address iLUC on 17 October 2012. EU Member States published National Renewable Energy Action Plans (NREAPs) during 2011, which include the scenarios and measures for the support of different types of renewable energy sources for all sectors, including biofuels and other renewable energy options needed for transport to meet the 2020 targets.

\section{The research project}

The EC-funded project Bioenergy, Sustainability and Trade-offs: Can We Avoid Deforestation while Promoting Biofuels? (EuropeAid/ ENV/2007/143936/TPS) was implemented by the Center for International Forestry Research (CIFOR) during the period September 2008 to March 2012. The key partners were the Council for Scientific and Industrial Research (CSIR) in South Africa, the Universidad Nacional Autonoma de México (Mexico), Joanneum Research (Austria), Stockholm Environment Institute (Sweden) and Profundo (The Netherlands). An evaluation of the project by the consulting group Resources \& Synergies Development was completed in June 2012.

The project aimed to contribute to the three aims defined in the EU Strategy for Biofuels, and to assess the implications of biofuel development and the policy responses to promote sustainable production, through scientific research and outreach activities that sought to inform ongoing policy dialogues and knowledge 
exchanges. The overall objective of the project was to foster sustainable bioenergy development that benefits local people in developing countries, minimises negative impacts on local environments and rural livelihoods, and contributes to global climate change mitigation. The main objective was to produce and communicate policy-relevant analyses that can inform government, corporate and civil society decision-making related to bioenergy development and its effects on forests and the poor. The project focused on six countries in three regions: South-East Asia (Indonesia and Malaysia), sub-Saharan Africa (Ghana and Zambia) and Latin America (Brazil and Mexico).

The work encompassed several areas of research with emphasis on: i) understanding the global trends in investment, production and consumption of biofuels, and their implications for forests; ii) assessing the institutional and legal frameworks, as well as market-based instruments, which influence the governance arrangements that affect biofuel development; iii) evaluating the social and environmental impacts of biofuel feedstock production, mediated by different institutional, economic and biophysical conditions across several case studies; iv) reviewing existing methods for carbon accounting, and formulating improved methods; v) analysing carbon emissions related to different scenarios of biofuel production; and vi) promoting a sciencepolicy dialogue and disseminating research findings. The main findings of these areas of research are presented in the sections below. The outputs of the project have been disseminated through CIFOR's Working Papers, Occasional Papers, Info Briefs, scientific journal articles, and other web-based materials (see the section on Promoting a policy-science dialogue, below).

\section{Global trends in investment, production and consumption of biofuels}

During the period 2000-2009, global output of biofuels increased by $400 \%$. Global trade also increased substantially such that approximately one-sixth of the biofuel produced in tropical regions was exported in 2009, with predominant trade flowing from countries in the global south to the US and EU. Biofuels increasingly utilise fractions of common starch, sugar and oilseed crops. The demand for land to expand the production of biofuel feedstocks grew throughout the period 2000-2010, albeit with substantial regional variation, and significant differences between feedstocks. For example, the growth in production of soy is largely attributable to demand for animal feed.

No reliable statistics on global biofuel investments exist. To achieve a better understanding of biofuel-related investments in forest-rich countries, 20 country-feedstock pairs in 16 countries distributed across select forest eco-regions in sub-Saharan Africa, Asia and Latin America were studied. Each case study examined investments made in the period 2000-2009 in one of four biofuel feedstocks (oil palm, soy, sugar cane and jatropha), as well as in biofuel production based on these feedstocks. These investment figures were corrected for the percentage of the different crops used for biofuels. Based on this calculation, we found that between US\$ 5.3 and 7.3 billion was invested in feedstock cultivation for biofuels. The lion's share was invested in oil palm in Asia (US\$ 2.0-2.9 billion) and sugar cane in Brazil (US\$ 2.2-2.8 billion). Although seven case studies focused on jatropha cultivation, only a small amount was invested in this crop: US\$ 175-290 million (Table 1).

The investments in biofuel feedstocks included all costs associated with acquisition of land, and the production of feedstocks. Many of the investments in feedstock growing are targeted at exporting feedstocks to foreign markets, to be converted into biofuel there. In contrast, investments in biofuel production included all costs associated with biofuel refining. In some cases, domestic production of biofuel is planned but has not yet materialised. In 7 out of our 20 case studies we found actual investments in biofuel refining took place in the period 2000-2009 for a total investment of US\$ 5.7-6.7 billion. Twothirds of these investments were targeted at producing ethanol from sugar cane in Brazil. One-third was targeted at producing biodiesel from soy and oil palm in Brazil, Indonesia and Malaysia. Few investments were found in producing biodiesel from jatropha seeds. To sustain growing global demand, significant amounts of additional investment are anticipated in the future (Table 2).

The 20 case studies showed that investments in both feedstock and biofuel production were made by a wide variety of companies, including relatively small domestic and foreign startups, larger agricultural companies, and companies from other sectors such as the oil industry. These included both publicly traded and state-owned firms. To finance their investments in biofuel and related feedstocks, these companies called upon an even broader array of financiers: domestic and foreign entrepreneurs, government agencies, public and private banks, and institutional investors. A total of more than 400 financial institutions were involved in the 20 case studies. About onequarter of these financiers are based in the case study countries, while three-quarters are foreign. Ninety per cent are private banks and institutional investors such as pension funds, asset

Table 1. Feedstock investments devoted to biofuel, for the period 2000-2009 (million US\$)

\begin{tabular}{lcccccc}
\hline Region & Countries researched & Sugar cane & Jatropha & Oil palm & Soy & Total \\
\hline Africa & 9 & 3 & $50-81$ & $22-33$ & $75-117$ \\
Asia & 3 & & $120-200$ & $1980-2970$ & $2100-3170$ \\
Latin America & 4 & $2240-2800$ & $5-9$ & $301-430$ & $612-756$ & $3158-3995$ \\
Total & 16 & $2243-2803$ & $175-290$ & $2303-3433$ & $612-756$ & $5333-7282$ \\
\hline
\end{tabular}




\section{Table 2. Investments in biofuel production, for the period 2000-2009 (million US\$)}

\begin{tabular}{lccc}
\hline $\begin{array}{l}\text { Biofuel from } \\
\text { feedstock }\end{array}$ & $\begin{array}{l}\text { No. of } \\
\text { countries } \\
\text { researched }\end{array}$ & $\begin{array}{l}\text { No. of countries } \\
\text { with biofuel } \\
\text { investments }\end{array}$ & $\begin{array}{l}\text { Total biofuel } \\
\text { investment } \\
\text { (US\$ million) }\end{array}$ \\
\hline Jatropha & 7 & 1 & $10-20$ \\
Oil palm & 6 & 3 & $1200-1600$ \\
Soy & 2 & 1 & $700-900$ \\
Sugar cane & 5 & 2 & $3800-4200$ \\
Total & 20 & 7 & $\mathbf{5 7 0 0 - 6 7 0 0}$ \\
\hline
\end{tabular}

managers and insurance companies. Only two banks were identified (Rabobank and Standard Chartered) that had developed internal investment guidelines for biofuel investments. Host country and consumer market governments alike should apply similar environmental and social conditions to all forms of public financing — subsidies, export credits, development loans and investments by state-owned companies_-and to companies in the biofuel supply chain. Domestic governments and governments of foreign countries from which financiers originate could also adopt regulations that incentivise private financial institutions to develop and apply responsible financing policies.

\section{Governance arrangements shaping biofuel development}

The CIFOR country and regional studies have highlighted the fact that many developing countries, particularly those in subSaharan Africa, have faced difficulties in attracting foreign direct investment for biofuel feedstocks and biofuel production per se. The potential positive and/or negative impacts of this trend will, however, often depend on the location, set-up and focus (exportoriented or domestic market) of the biofuel investments. Despite the recent stagnation in the expansion of biofuel production in developing countries, producers do appear highly responsive to changes in global market conditions (e.g. export opportunities). As biofuel production becomes financially viable-for example, with higher oil prices, efficiency gains, or as more biofuel blending mandates come into effect - the sector will likely revitalise rapidly.

Although the future expansion of biofuels could generate various economic benefits related to import substitution, increased export earnings and other co-benefits (e.g. rural employment, improved service delivery in rural areas, and the more efficient use of biomass compared with traditional uses), negative externalities (e.g. loss of customary lands and forest resources as the main means to sustain the livelihoods of rural people, and increases in trade-based emissions) could also result. Many host countries have not adopted biofuel-specific sustainability regulations and often lack the legal and institutional frameworks to effectively mitigate the negative impacts and capture the positive impacts of sector development (German and Schoneveld. 2012). Poor track records in regulatory implementation and enforcementfor example, in relation to customary land rights, environmental protection, and smallholder economic integration-are of particular concern. Many national governance systems are still poorly equipped to deal effectively with biofuel development. Nevertheless, biofuels are not produced in isolation from other agricultural and forest products and services. Hence, the need to develop broader land use optimisation regulations and incentives.

Concrete efforts to address these concerns are being developed, such as the sustainability criteria of the EU RED, as well as a number of host country sustainability policies and crop- and sector-specific certification systems. In practice, many of these initiatives still lack sufficient legislative force or effective monitoring and enforcement mandates. Current efforts to discourage poor practices on the ground have therefore had limited effect. Effectiveness has been undermined not only by host country capacity constraints, but also by the limited adoption of 'hard' sustainability standards, poor commitment by banks and other financial institutions to mainstream and implement responsible investment policies, a lack of coordination between the different systems of governance, and the need for crosssectoral solutions to the challenge of indirect land use change.

In some countries, foreign investors have been able to negotiate access to large areas of land outside of statutory frameworks, and often also without complying with either national investment and/or environmental impact assessment regulations (e.g. the case of Ghana). Multiple regulatory requirements and standards have increased the opportunities for investors to shop and choose institutional entry points that best align with the investor's strengths and weaknesses. This outcome is due in part to the fact that voluntary sustainability schemes are not the only instrument for ensuring the adoption of sustainable practices. In this regard, more effective and integrated governance architectures will be required to manage these distributional distortions, including the adoption of bilateral and multilateral agreements.

Acknowledging that capital flows play an important role in enabling the growth of the biofuel sector, it is critical to understand the broad variety of financiers involved, ranging from domestic and foreign entrepreneurs to government agencies, public and private banks, and institutional investors such as pension funds and insurance companies. Some of these originate from host countries, some from consumer countries and others from China and some Middle East countries. For host country governments, the policy priority should be enhancing market accountability through tighter regulations on biofuel production, while governments in consumer countries should strengthen import criteria such as those given by the EU RED. Producers and traders should commit to production and import standards, while the financial sector should adopt more responsible financing policies based on measurable, reportable and verifiable principles, criteria and indicators shaped by internationally accepted standards. Finally, to strengthen such public and private governance initiatives, greater complementarities need to be explored between the various governance instruments - for example, consumption standards, responsible financing policies, certification systems, and host country policy frameworks-and to provide them with the necessary legislative backing (Pacheco et al. 2011). This is where normative guidelines, such as codes of conduct, could potentially be very useful. 


\section{Socio-economic and environmental impacts of biofuel feedstock production}

\section{Socio-economic impacts}

Food security is dependent on a complex range of issues linked to sustainability, availability, affordability, access and utilisation, and not to production alone. Increases in food production over the past 50 years have been made largely through plant breeding but often at the cost of forest biodiversity and ecosystem service provision. It is evident that new ways need to be found to feed the world's population both efficiently and equitably given anticipated growth to over 9 billion by 2050. Not only will there be more mouths to feed, but increasingly wealthy societies will demand a more (animal) protein-rich diet, which will require considerable additional land and investment. With much of the world's productive land already under some form of cultivation, policy makers are struggling to reconcile the need to grow additional food with the need to avoid encroaching on already threatened natural ecosystems, especially forests. Some advocate a process of 'land sharing', whereby agricultural production takes place within complex multifunctional landscapes. Others favour 'land sparing', where agricultural production on already cultivated or marginal lands is maximised, so that other areas are set aside for the conservation of biodiversity (Phalan et al. 2011, Tilman et al. 2011). Globalisation is increasingly shaping patterns of resource allocation and trans-boundary flows of goods and capital. Developing countries are being incorporated into international markets as suppliers of food, animal feed, and biofuel feedstocks, a trend which has resulted in a sharp rise in large-scale commercial agricultural investments in many countries in Asia, sub-Saharan Africa, and Latin America (Lambin and Meyfroidt 2011)

The local social and economic impacts of biofuel feedstock investments are extremely variable in terms of both the type of investment, and the different groups affected by such investments. For industrial-scale plantations, it is essential to explore the differential impacts experienced by plantation employees, and by households losing land or forest resources to companies and contracted growers. The voluntary nature of employment and the scarcity of regular cash income in many rural areas mean that livelihood impacts from formal employment tend to be positive among those capable of securing formal plantation employment. Benefits are often expressed in net increases in household income, improved social services available to employees and more regular income flows. However, net benefits to employees do not always accrue. In some cases, poor working conditions coupled with difficulties associated with the shift from traditional livelihood activities to waged labour, may lead to net declines in livelihood conditions for employees.

In contrast, customary rights holders who have lost land to investors tend to experience net negative effects on their livelihoods. This was particularly true for sites characterised by the transfer of large areas of land by customary leaders, rather than voluntary transactions among individual buyers and sellers. Frequently, the land transferred by the customary leaders affected many households that held less secure, and often derived rights. Derived rights are those that accrue to an individual but which originate from, and depend on, their relationship with another person, usually through parenthood, marriage or cohabitation. Economic losses resulted from the loss of agricultural and forest incomes (derived notably from subsistence use and/or sale of non-timber forest products), and from the difficulties faced in trying to reconstruct new livelihood opportunities. Land transfers have often involved some form of compensation. However, the variability in the actual compensation paid to different communities linked to the poor governance of the payments received within affected communities has meant that the potential for compensation to translate into livelihood opportunities for affected households has largely failed to materialise. Furthermore, in several case study countries, companies preferred to hire labour from outside the area-to the great disappointment of affected land users - repeating historical patterns of plantation establishment (e.g. Slocomb 2007).

Finally, for the case of small-scale contracted growers, growing biofuel feedstocks for larger operators can provide access to inputs, services and markets that may otherwise have been difficult to acquire. In Malaysia and Indonesia, for example, traditional land uses of smallholders have increasingly given way to oil palm because of the significant economic advantages it provides. Yet evidence from several countries suggests that those with more land or capital are better able to capture the opportunities associated with such emerging industries. In Indonesia, at sites where households were wealthier and with better knowledge of markets, small-scale growers were able to establish more beneficial partnerships with industry partners. In contrast, unfavourable terms and conditions of smallholder contracts and uncertain markets led to a situation in which smallholders bore much of the risk of the emerging jatropha industry in sub-Saharan Africa.

\section{Environmental impacts}

The expansion of multipurpose feedstocks that can also be used as biofuels, is often part of industrial-scale investments and was directly associated with deforestation in most case study sites. The proportion of such feedstock expansion occurring at the expense of forests ranged from 13 to $99 \%$ of the total area. The highest rates were observed for oil palm plantations in Indonesia, and the lowest for soy in Brazil. Nonetheless, the multipurpose nature of oil palm and soy in terms of end-use mean that only a small proportion of deforestation is actually attributable to the biofuel sector per se (Box 1).

These findings illustrate both the risks associated with plantation crops in penetrating forest landscapes, and the challenges of estimating indirect land use changes associated with the expansion of biofuel feedstocks in areas with different land use histories (Gao et al. 2011 and Di Lucia et al. 2012). Additional research is needed to better understand land use change trajectories before setting up any biofuel plantations, and to estimate indirect land use changes. Some economic modelling has already been attempted by the International Food Policy 


\section{Box 1. Estimating deforestation associated with soy production, Mato Grosso, Brazil}
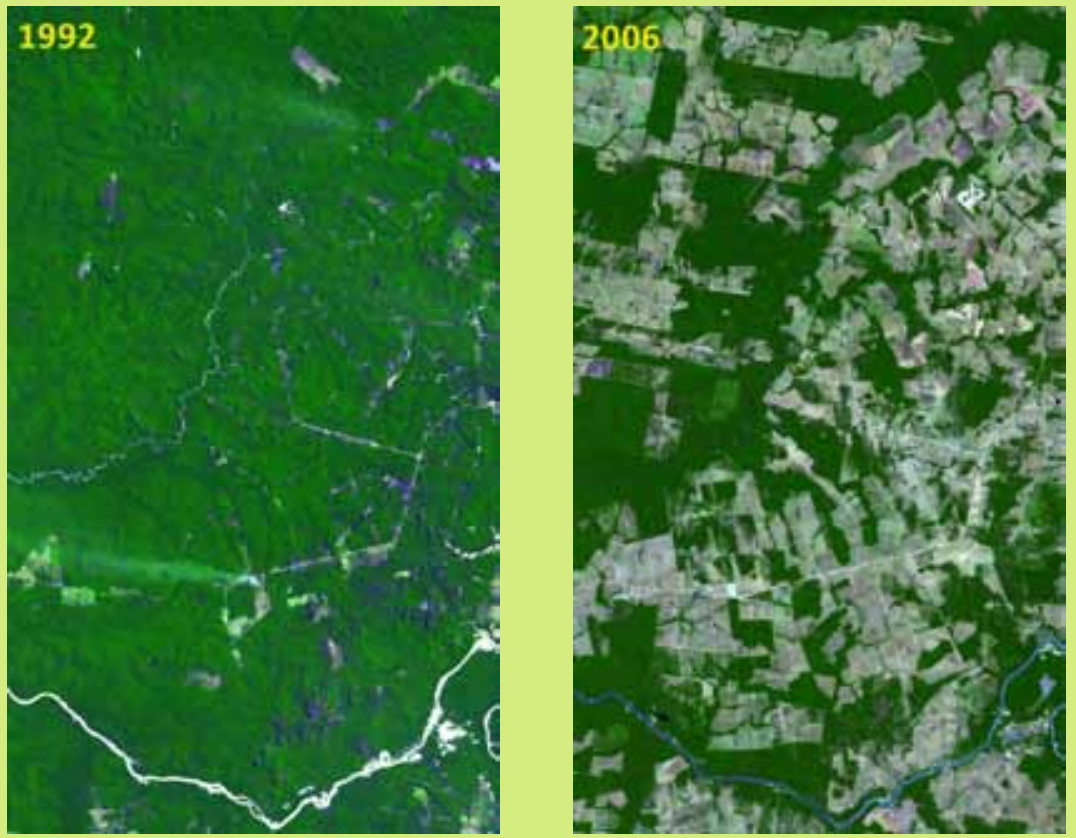

- Direct impact is low since a major portion of soy expansion takes place on pasture lands. This may lead, however, to indirect forest conversion by displacing cattle.

- About $20 \%$ of deforestation is attributable to soy, but oil makes up only $14 \%$ of the total weight of soy. An estimated $35 \%$ of soy oil may be used in biodiesel production.

- A range of 1.5\%-7\% deforestation is estimated to be attributable to biofuels, depending on the allocation method used.

Source: Jet Propulsion Laboratory, NASA (2008)

Maps by NASA/GSFC/METI/ERSDAC/JAROS, and U.S./Japan ASTER Science Team

Research Institute (see http://trade.ec.europa.eu/doclib/ docs/2011/october/tradoc_148289.pdf). In the Brazilian case, the combination of stringent government regulations on forest conversion, use of satellite imagery to monitor compliance, and a moratorium on soy grown in newly deforested areas have gone a long way to minimise forest conversion associated with direct land-use change (May-Tobin et al. 2012).

The expansion of biofuel feedstocks in selected cases did occur into secondary forests and fallows. However, degraded land was not targeted for cultivation in any of the cases. These findings exemplify that this research project focused on feedstock expansion in landscapes with significant forest and woodland cover. Many producer countries and investors target forested areas for agro-industrial expansion to minimise negative effects on food security, avoid land appropriation and resettlement issues, and maximise timber revenues to offset early investment costs. Smallholder production systems often have a very different social and environmental 'signature' than industrialscale plantations. Furthermore, the tendency to assume that landscapes shaped by a history of timber extraction or fire as a management tool (e.g. hunting, grazing and shifting agriculture) are by definition 'degraded' continues to underestimate the total economic value of forests and woodlands, and thus the full costs associated with conversion. Aside from the difficulties of finding large enough contiguous areas of degraded land, the profit motive also deters investors from targeting such lands in practice since this will incur loss of revenues from timber, and the risks of litigation and compensation due to spontaneous settlement by smallholders (German et al. 2011).

The ecological costs associated with forest conversion are diverse (Guarigata et al. 2011). In addition to loss of biodiversity, local communities identified a host of environmental impacts directly impinging upon their lives and livelihoods. These included a decline in air and water quality due to factory effluent/emissions and land cover change; a perceived increase in crop and human pests and disease; degradation of protected forests due to encroachment, harvesting pressure and fire; and increased flooding in cases where peatland forests were converted to oil palm. However, it is the implications of these land use changes with regard to the climate change mitigation potential of biofuels that is of paramount importance. Significant carbon debts were found to accrue from direct and total (direct + indirect) land use change, in the range of 254-1579 tonne/ha $\mathrm{CO}_{2}$ equivalent (eq.) and 266-1744 tonne/ha $\mathrm{CO}_{2}$-eq, respectively. While 
significant carbon debts accrued in all sites involving forest and woodland conversion, the larger debts were derived from sites where carbon-rich peatland forests were converted (e.g. West Kalimantan, Indonesia). Total carbon debts associated with soy and jatropha were found to be significantly lower than for other feedstocks. Carbon debts were found to postpone net GHG reductions from biofuels by 18 to 629 years, raising the question of whether it is appropriate for biofuel feedstocks produced on either (relatively) pristine or 'degraded', humid or dry forest landscapes, to be considered ecologically friendly. However, all biofuels used in the EU are required to reduce GHG emissions by at least 35\% compared with the use of fossil fuels, including the emissions from direct and indirect land use changes. The biofuels used in the EU would therefore not possibly have such long payback times, as they need to comply with the sustainability criteria set out in both the EU RED and the EU Fuel Quality Directive.

\section{Accounting for bioenergy's $\mathrm{CO}_{2}$ emissions}

Accounting for carbon dioxide $\left(\mathrm{CO}_{2}\right)$ emissions associated with bioenergy, as done under the Kyoto Protocol (KP) and European Union (EU) Emissions Trading Scheme, fails to capture the full extent of these emissions because the biomass may be sourced outside the reporting area. As a consequence, other accounting approaches have been proposed. Both the EU and the USA already use value-chain approaches to determine total GHG emissions associated with the production, transport and use of biofuels - an approach quite different from that of the KP. Further, both the EU and the USA are engaged in consultation processes to determine how emissions associated with the use of biomass for heat and power will be addressed under regulatory systems. The USA is considering whether $\mathrm{CO}_{2}$ emissions from biomass should be treated like fossil fuels. In this context, the project developed three potential accounting alternatives, as follows.

1. $\mathrm{CO}_{2}$ emissions from bioenergy are not counted at the point of combustion. Instead emissions due to use of biomass are accounted for in the land use sector as carbon stock losses. This is the KP approach.

2. $\mathrm{CO}_{2}$ emissions from bioenergy are accounted for in the energy sector with or without $\mathrm{CO}_{2}$ removals accounted for in the land use sector. These two options are a Point-of-uptake (POUR) approach and a Tailpipe approach, respectively.

3. End users account for all or a specified subset of $\mathrm{CO}_{2}$ emissions, regardless of where these emissions occur geographically. This is a value-chain approach.

Numerical examples were calculated to illustrate the impacts of the different accounting approaches at local and international levels (Figure 2). The international estimates made extensive use of the results from the GLOBIOM model (Havlik et al. 2011). These estimates were extended to include emissions from dead wood, litter and soil organic carbon. These additional carbon pools were shown to increase emissions from biofuel use by approximately 20\% (Bird et al. 2011).

The current accounting system for emissions from bioenergy sources gives entities with GHG obligations an incentive to use biofuels at the expense of maintaining carbon stocks. The problem arises because the KP's accounting of bioenergy is a '0-combustion factor' approach. Emissions from the combustion

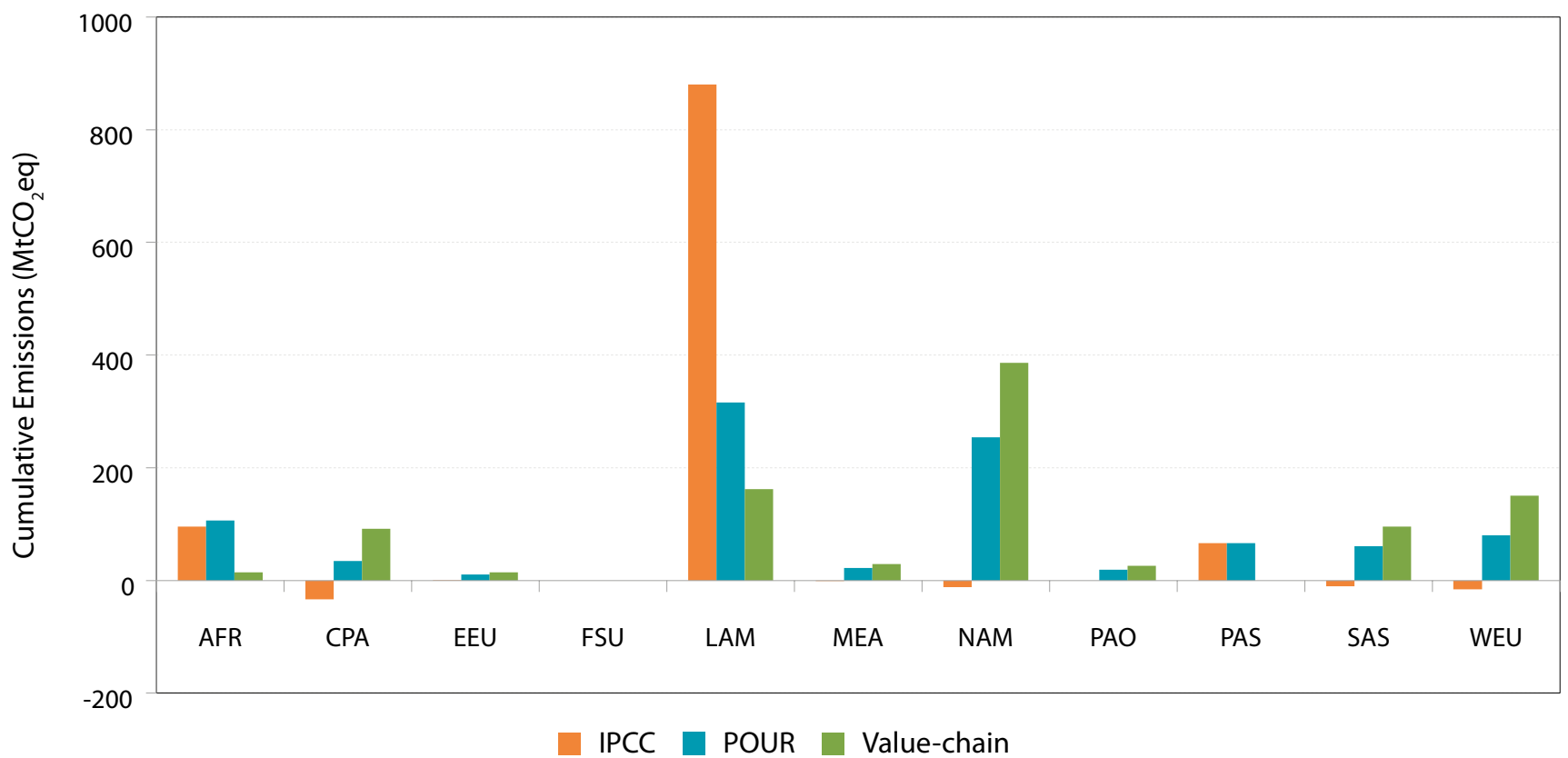

Figure 2. Cumulative emissions from biofuels to 2030 by region under different accounting systems

Abbreviations: AFR = sub-Saharan Africa, CPA = centrally planned Asia, EEU = Central and Eastern Europe, FSU = Former Soviet Union, $\mathrm{LAM}=$ Latin America, MEA = Middle East and North Africa, NAM = North America, PAO = Pacific OECD, PAS = Other Pacific Asia, SAS = South Asia, WEU $=$ Western Europe. Calculations are made by the authors but are based on data from Havlik et al. (2011). 
of biomass for energy are not accounted for in the energy sector but in the land use sector as carbon stock losses. However, in reality, many carbon stock losses are not accounted for. Value-chain approaches encompass not only emissions from combustion of biomass and carbon stock losses, but also emissions from cultivation of biomass and its conversion and transportation. In addition, unlike other existing approaches, they hold a consuming nation responsible for emissions that occur outside of its national boundaries.

The alternative accounting systems were also evaluated against general criteria and for impacts on selected stakeholder goals. General criteria considered were: (a) comprehensiveness, (b) simplicity, and (c) scale independence. Stakeholder goals reviewed were: (a) stimulation of rural economies, (b) food security, (c) GHG reductions, and (d) preservation of forests (Table 3).

\section{Potential impacts of changes in biofuel technology}

The GHG emissions of selected first- and second-generation pathways were examined in Mexico, Indonesia and South Africa. Differences in the feedstock, conversion technologies and input parameters used in each country result in different GHG emissions per unit of energy in the fuel (i.e. GHGs per megajoule) The emissions analysed included GHG emissions from LUC, cultivation, processing and transport of biofuels up to their first point of distribution and potential export to Europe. Calculations, except for the LUC component, were made using the EU-funded BioGrace tool, which was designed to meet the requirements set out in the EU RED.

The biofuel production pathways were analysed for biodiesel produced from oil palm in Indonesia; biodiesel from jatropha in South Africa and Mexico; bioethanol from sugar cane in South Africa, Mexico and Indonesia; bioethanol from wood in South Africa and Mexico; and Fischer-Tropsch diesel from wood in South Africa and Mexico (Figure 3). The following GHGs were considered: carbon dioxide $\left(\mathrm{CO}_{2}\right)$, methane $\left(\mathrm{CH}_{4}\right)$ and nitrous oxide $\left(\mathrm{N}_{2} \mathrm{O}\right)$. GHG emissions are allocated to the biofuel and its co-products (e.g. seedcake) using the energy allocation method, that is, according to their relative energy content. Finally, three sensitivity analyses were carried out on the following parameters, viz:
- domestic use of the biofuel vs. its export to the EU in cases where both scenarios are considered likely;

- effect of different jatropha productivity rates in Mexico; and

- use of the co-product for fertilisation vs. export of the co-product and use of mineral fertilisers in the case of biodiesel from jatropha in sub-Saharan Africa.

The emissions from land use change (LUC) are based on using the GLOBIOM model which resulted in three default values for LUC emissions, viz.,

- $118 \mathrm{~g} \mathrm{CO}_{2}$-eq per MJ fuel produced for non-wood feedstocks;

- $0.4 \mathrm{~g} \mathrm{CO}_{2}$-eq per MJ fuel produced for wood taken from short rotation coppices; and

- $-10.7 \mathrm{~g} \mathrm{CO}_{2}$-eq per MJ fuel for residues and woodchips taken from existing forests.

The results indicate that the dominance of the high LUC value means that the lowest emission pathways use wood as the feedstock. However, all of these require $2 \mathrm{G}$ conversion technologies. The $1 \mathrm{G}$ pathways with the lowest emissions are bioethanol from sugar cane in Mexico and Indonesia. The sensitivity analyses on jatropha show that feedstock productivity strongly influences emissions from cultivation. Analysis on the use of inorganic fertiliser compared with fertiliser using seedcake resulting from jatropha cultivation in sub-Saharan Africa shows that the use of inorganic fertiliser leads to much higher emissions from cultivation.

The sensitivity analysis on emissions from transport shows that, even where exports to the EU occur, transport emissions constitute only a minor share of the total emissions. The relative importance of transport emissions increases, particularly when LUC emissions are low, that is, for pathways using wood as feedstock.

\section{Promoting a policy-science dialogue on sustainable and equitable biofuels}

The project actively engaged with a wide range of stakeholders in a process of outreach and dissemination of research results, particularly in the period 2010-2011. Meetings with European Parliamentarians, civil society, and government ministries demonstrated the value of the research and the potential applicability of model bioenergy policies to countries beyond the project zone (during 2011, CIFOR's publications were downloaded

Table 3. Qualitative review: accounting approaches versus criteria and stakeholder goals

\begin{tabular}{llllllll}
\hline $\begin{array}{l}\text { Accounting } \\
\text { approach }\end{array}$ & Comprehensiveness & Simplicity & Scale & $\begin{array}{l}\text { Stimulate rural } \\
\text { economies }\end{array}$ & $\begin{array}{l}\text { Protect food } \\
\text { security }\end{array}$ & $\begin{array}{l}\text { Reduce GHG } \\
\text { emissions }\end{array}$ & Preserve forests \\
\hline KP & Low & High & Low & High & Low & Low & Low \\
POUR & High & Medium & Low & $\begin{array}{l}\text { DPD, } \\
\text { potentially high }\end{array}$ & Potentially low & $\begin{array}{l}\text { DPD, } \\
\text { potentially high }\end{array}$ & $\begin{array}{l}\text { DPD, } \\
\text { potentially high }\end{array}$ \\
Value-chain & Very high & Low & Low & DM & Low & High & High \\
\hline
\end{tabular}

The evaluation of POUR assumes a mechanism to award and transfer credits from producer to consumer.

$\mathrm{DPD}=$ depends on programme details. $\mathrm{DM}=$ depends on mandate. 


\section{0}
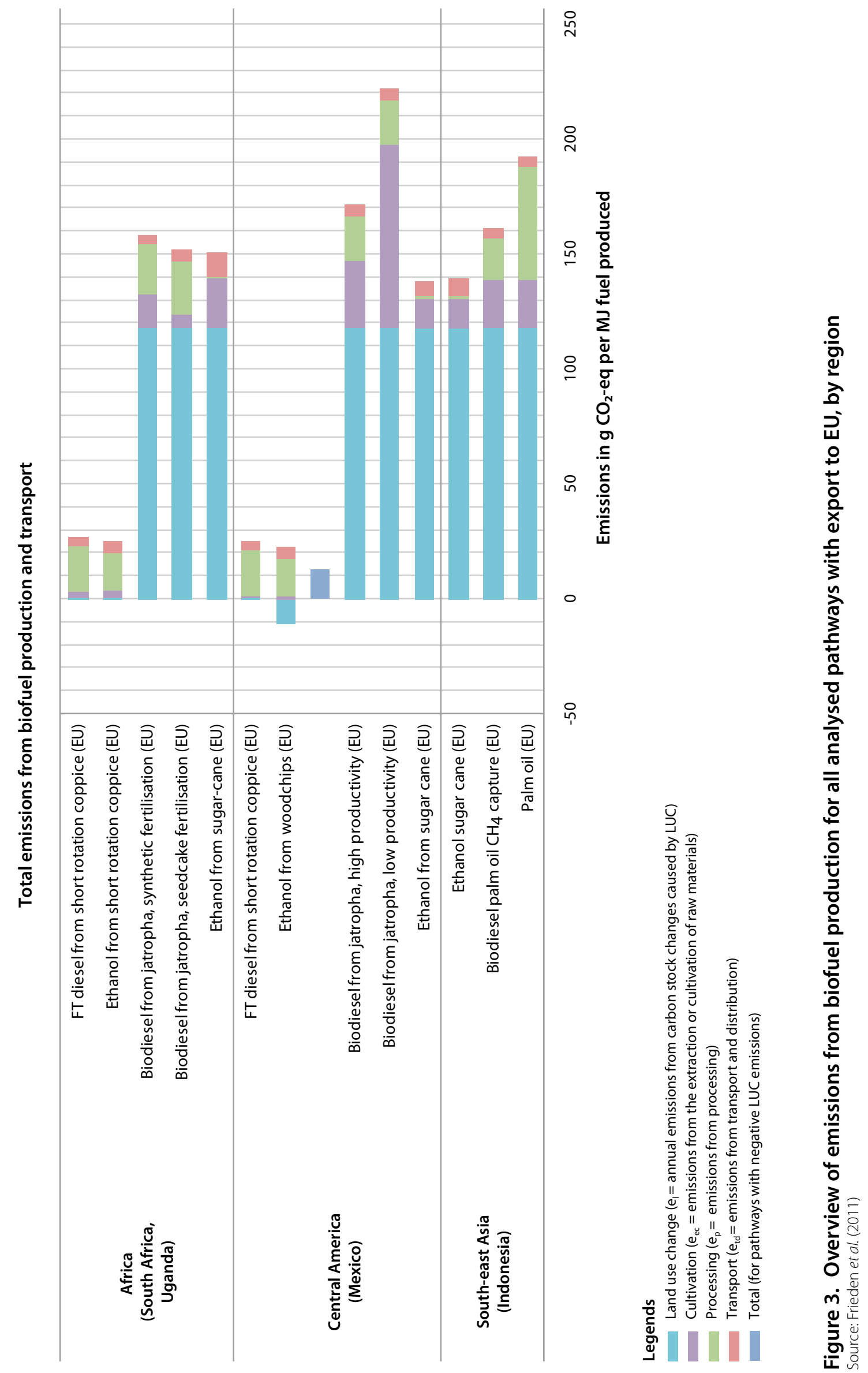
169632 times, suggesting there is considerable global demand for evidence-based information about biofuels).

CIFOR hosted a South-South exchange in September 2011 Sharing what works in sustainable and equitable oil palm development for food and biofuels - with 20 representatives from government, industry, and non-governmental and research entities from Indonesia, Malaysia, Brazil, Colombia, Ghana and Cameroon. This included a site visit to a RSPO-certified producer in Riau province, and culminated in their participation in a conference titled Forests Indonesia-Alternative futures to meet the demands for food, fibre, fuel and REDD+, which was opened by the President of Indonesia. CIFOR hosted a similar exchange in Pretoria, South Africa in the same month-Mitigating impacts, and enhancing rural livelihood and national economic benefits from biofuel expansion in the woodland areas of Africa - that included 12 representatives from 9 SADC member states and 3 others from Brazil, Indonesia and Malaysia. CIFOR's research results were also presented at an international workshop in Campinas, Brazil on the theme Quantifying and managing land use effects of bioenergy. This was jointly organised by the International Energy Association Bioenergy Tasks 38/40/43 and the Brazilian Bioethanol Science and Technology Laboratory. It brought together state-of-the-art research concerned with assessing land use effects of bioenergy, mitigating negative impacts, and promoting beneficial outcomes (further details are available at http://ieabioenergy-task38.org/ workshops/campinas2011/). Finally, CIFOR hosted a side event, Biofuel development and forests: Impacts and implications for governance, as part of the Durban Trade and Climate Change Symposium organised by the International Centre for Trade and Sustainable Development, The World Trade Organization and the Department of Trade and Industry of the Republic of South Africa (further details are available at http://www.ictsdclimate.org/en/ events/the-durban-trade-and-climate-change-symposium).

\section{Addressing new biofuels challenges and identifying further research needs}

Many sustainability certification schemes are vying for approval by the EU and the private sector as the biofuel market has been rapidly transformed. Technological advances, especially via $2 \mathrm{G}$ biofuels, have brought the biofuel industry closer to other biomass-based industries, such as pulp and paper or forestry. In the longer term, it is expected that bio-refineries will produce multiple energy and non-energy products in a flexible and more efficient manner. The option of different final markets also implies increased competition for feedstock, just as agricultural biofuels created some competition with food and/or animal fodder. This blurs the boundaries between biofuels and biomass, opening options for broader and more comprehensive sustainability initiatives that can cover all biomass-based materials and products or services (Johnson et al. 2012).

A significant challenge remains for the $\mathrm{EU}$ and partner countries in the developing world: how does one achieve food and energy security while mitigating climate change in the context of a growing global population that is expected to reach 9 billion by 2050 ? The options available are influenced by increasing global economic and market integration. Globalisation is increasingly shaping patterns of resource allocation and trans-boundary flows of goods and capital. Within this context, developing countries are increasingly being incorporated into international markets as suppliers of food, feed, and fuel. Therefore, the governance of these processes and their impacts on local and national development, the livelihoods of the rural poor and the environment will depend on more complex institutional architectures. Such architectures must comprise not only disparate policy frameworks in producer countries, but also market regulations in consumer countries aimed at ensuring the sustainable and responsible supply of food, feed and biofuel feedstocks. Voluntary schemes have thus far been the main instrument for addressing the sustainability of biofuels used in the EU. Further analysis on the opportunities and effectiveness of other approaches, particularly bilateral and multilateral agreements, could address some of the shortcomings of the current voluntary schemes, particularly in relation to the need for institutional strengthening and technical support in Least Developed Countries and for smallholder producers of biofuel feedstocks.

A second-phase project, Biofuels, food and forests: Enhanced governance for sustainable options that work for forests and the poor, has been proposed. This aims to continue contributing to the EU policy goals of helping developing countries to make progress on sustainable energy options, while still ensuring food security. It also aims to reduce the ecological footprint of growing demand for biofuels, and the large-scale investments that target food and biofuel production. The research findings will assist in promoting sustainable pathways for the development of green economies that meet growing consumption needs in consumer countries, along with sustainable and equitable growth in developing countries.

\section{Selected references}

Achten, W. and Verchot, L. 2011 Implications of biodieselinduced land use changes for $\mathrm{CO}_{2}$ emissions: case studies in tropical America, Africa, and Southeast Asia. Ecology and Society 16 (4): 14. http://dx.doi.org/10.5751/ES-04403-160414.

Bird, D.N., Pena, N. and Zanchi, G. 2011 Alternative $\mathrm{CO}_{2}$ accounting for bioenergy: 0, 1, or in between. Global Change Biology Bioenergy GCB Bioenergy 4 (5): 576-587.

Di Lucia, L., Ahlgren, S., and Ericsson, K. 2012 The dilemma of indirect land use changes in EU biofuel policy An empirical study of policy making in the context of scientific uncertainty. Environmental Science \& Policy 16: 9-19.

Eisentraut, A. 2010 Sustainable production of second generation biofuels: potential and perspectives in major economies and developing countries. International Energy Agency, Paris, France.

Fisher, G., Hiznyik, E., Prieler, S., Shah, M. and van Helthuizen, H. 2009 Biofuels and food security. IIASA, OFID, Vienna, Austria.

Frieden, D., Pena, N., Bird, N., Schwaiger, H., and Canella, L. 2011 Emission balances of first- and second-generation biofuels: case studies from Africa, Mexico and Indonesia. CIFOR Working Paper No. 70. Bogor, Indonesia. 
Gao, Y., Skutsch, M., Drigo, R., Pacheco, P. and Masera, O. 2011 Assessing deforestation from biofuels: Methodological challenges. Applied Geography 31 (2): 508-518.

German, L. and Schoneveld, G. 2012 Biofuel investments in Sub-Saharan Africa: A review of the early legal and institutional framework in Zambia. Review of Policy Research 29 (4): 467-491http://dx.doi.org/ http://dx.doi.org/10.1111/ j.1541-1338.2012.00572.x.

German, L., Schoneveld, G. and Pacheco, P. 2011 Editorial: The social and environmental impacts of biofuel feedstock cultivation: evidence from multi-site research in the forest frontier. Ecology and Society 16 (4): 24. http://dx.doi. org/10.5751/ES-04309-160324.

Guariguata, M., Masera, O., Martínez-Bravo, R., Johnson, F., Tella, P. Von Maltitz, G., and Bird, N. 2011 A review of environmental issues in the context of biofuel sustainability frameworks. CIFOR Occasional Paper No. 69. Bogor, Indonesia.

Havlik, P., Schneider, U.A., Schmid, E., Bottcher, H., Fritz, S., Skalskyl, R., Aoko, K., de Cara, S., Kindermann, G. et al. 2011 Global land use implications of first and second generation biofuel targets. Energy Policy 39 (10): 5690-5702.

Jet Propulsion Laboratory, California Institute of Technology, NASA 2008 Advanced Spaceborne Thermal Emission and Reflection Radiometer (ASTER). http://www.jpl.nasa.gov/spaceimages/ details.php?id=PIA11420 (24 September 2011).

Johnson, F., Pacini, H. and Smeets, E. 2012 Transformations in EU biofuels markets under the Renewable Energy Directive and the implications for land use, trade and forest protection. CIFOR Occasional Paper No. 78. Bogor, Indonesia.

Lambin, E.F. and Meyfroidt, P. 2011 Global land use change, economic globalization and the looming land scarcity. Proceedings of the National Academy of Sciences USA 108 (9): 3465-3472.
May-Tobin, C., Boucher, D., Decker, E., Hirowitz, G., Martin, J., Mulik, K., Roquemort, S. and Stark, A. 2012 Recipes for success solutions for deforestation-free vegetable oils. Union of Concerned Scientists and Climate Advisers USA. Cambridge, MA.

Pacheco, P., German, L. van Gelder, J.W., Weinberger K. and Guariguata, M. 2011 Avoiding deforestation in the context of biofuel feedstock expansion: an analysis of the effectiveness of market-based instruments. CIFOR Working Paper No. 73. Bogor, Indonesia.

Phalan, B., Onial, M., Balmford, A. and Green, R.E. 2011 Reconciling food production and biodiversity conservation: land sharing and land sparing compared. Science 333 (6047): 1289-1291.

Popp, A., Krause, M., Dietrich, J.P., Lotze-Campen, H., Leimbach, M., Beringer, T. and Bauer, N. 2012 Additional $\mathrm{CO}_{2}$ emissions from land use change - forest conservation as a precondition for sustainable production of second generation bioenergy. Ecological Economics 74: 64-70.

Resources \& Synergies Development. 2012 Evaluation report. Bioenergy, sustainability and trade-offs: can we avoid deforestation while promoting biofuels? Project (EuropeAid/ ENV/2007/143936/TPS), June 2012. CIFOR, Bogor, Indonesia.

Slocomb, M. 2007 Colons and coolies - the development of Cambodia's rubber plantations. White Lotus, Bangkok.

Smith, K.A. and Searchinger, T.D. 2012 Crop-based biofuels and associated environmental concerns. GCB Bioenergy 4(5): 479-484.

Tilman, D., Balzer, C., Hill, J. and Befort, B.L. 2011 Global food demand and the sustainable intensification of agriculture. Proc Natl Acad Sci USA 108:20260-20264.

This research was carried out by CIFOR as part of the CGIAR Research Programme, 'Forests, Trees and Agroforestry: Livelihoods, Landscapes and Governance.' The Programme aims to enhance management and use of forests, agroforestry and tree genetic resources across the landscape from forests to farms. CIFOR leads the collaborative Programme in partnership with Bioversity International, the International Center for Tropical Agriculture and the World Agroforestry Centre.
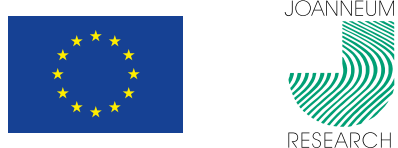

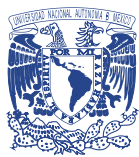

1...

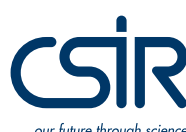

our future through science $\searrow \bigcirc \begin{aligned} & \text { stochlolm } \\ & \text { environiment } \\ & \text { institute }\end{aligned}$

cifor.org

blog.cifor.org 